\title{
„Straightaway Their Vision Came to Them”: Maya Ancestral Vision and Blood Memory
}

\author{
Allen J. Christenson
}

\begin{abstract}
:
According to the Popol Vuh, a Maya text compiled soon after the Spanish Conquest in the sixteenth century, the first men created by the gods had the gift of extraordinary vision whereby they could see all things: "Perfect was their sight, and perfect was their knowledge of everything beneath the sky. If they gazed about them, turning their faces around, they beheld that which was in the sky and that which was upon the earth. Instantly, they were able to behold everything. They didn't have to walk to see all that existed beneath the sky. They merely saw it from wherever they were. Thus, their knowledge became full. Their vision passed beyond the trees and rocks, beyond the lakes and the seas, beyond the mountains and the valleys" (Christenson 2007: 197). Although the creator gods eventually clouded this vision so that men could only see those things which were "nearby," the progenitors of the Maya and their descendents nevertheless bore within their blood the potential for divine sight, bestowed upon them by their creators. Present-day Maya traditionalist priests in the highlands of Guatemala believe that their divine ancestors, who set the pattern for contemporary rituals, continue to operate through them as conduits at appropriate times and under appropriate circumstances. It is their sacred ancestral vision that allows indigenous priests to "see" beyond the limits of time and distance as the first men once did as they conduct divination ceremonies connected with the ancient Maya calendar.
\end{abstract}

Keywords: K'iche', Highland Maya, vision

\section{Resumen:}

"LES LLEGÓ LA VISIÓN DE REPENTE": LOS HOMBRES DEL MAÍZ MAYAS Y LA MEMORIA DE LA SANGRE ANCESTRAL

De acuerdo con el Popol Vuh, un texto maya recopilado poco después de la conquista española en el siglo $X V I$, los primeros hombres creados por los dioses tenían el don de una vista extraordinaria mediante la cual podían ver todas las cosas. "Fueron dotados de inteligencia; vieron y al punto se elevó su vista, su mirada lo abrazó todo, alcanzaron a conocer todo lo que hay en el mundo. Cuando miraban, al instante veían lo que estaba a su alrededor y contemplaban en torno a ellos la bóveda del cielo y la superficie de

Allen J. Christenson • Brigham Young University, email: allen_christenson@byu.edu 
la tierra. Las cosas ocultas y distantes las veían todas a su voluntad, sin tener primero que moverse; en seguida dirigían la vista al mundo y veían igualmente todo lo que contiene. Grande era su sabiduría; su conocimiento abarcaba los árboles, las rocas, los lagos, los mares, las montañas y los valles" (Popol Vuh 2008: 128). Aunque los dioses creadores finalmente velaron esta visión para que los hombres solo pudieran verlo que estaba cerca, los progenitores de los mayas y sus descendientes, sin embargo, llevaban en su sangre el potencial de la visión divina, otorgado por sus creadores. En la actualidad, los sacerdotes tradicionalistas mayas de los Altos de Guatemala creen que sus ancestros divinos, quienes establecieron el modelo para los rituales contemporáneos, continúan actuando a través de ellos mismos en los momentos y las circunstancias apropiadas. Es esta perspectiva ancestral sacralizada la que permite a los sacerdotes indígenas "ver" más allá de los límites del tiempo y la distancia como lo hicieron los primeros hombres mientras realizaban ceremonias adivinatorias relacionadas con el antiguo calendario maya.

Palabras claves: K'iche', mayas de altiplano, visión

According to the Popol Vuh, a K'iche'-Maya text compiled in the highlands of Guatemala in the mid-sixteenth century, the first men created by the gods had the gift of extraordinary vision whereby they could see all things:

Perfect was their sight, and perfect was their knowledge of everything beneath the sky. If they gazed about them, turning their faces around, they beheld that which was in the sky and that which was upon the earth. Instantly, they were able to behold everything. They didn't have to walk to see all that existed beneath the sky. They merely saw it from wherever they were. Thus their knowledge became full. Their vision passed beyond the trees and rocks, beyond the lakes and the seas, beyond the mountains and the valleys (Christenson 2007: 197-198).

A slightly older K'iche' document, the Title of Totonicapán, describes the first highland Maya ancestors as people of great vision and power:

Then the enchanted people contemplated their journey. From far away they arrived in their obscurity in the sky and on the land. There are none to equal them. They saw everything beneath the sky. They were great sages (Title of Totonicapán; Folio 8 recto, lines 1-4; translation by author).

Although the creator gods eventually clouded this miraculous vision so that people could see only those things that were "nearby" (Christenson 2007: 201), the ancestors of the Maya and their descendants nevertheless believe that they bear within their blood the potential for divine sight. Today, Maya ritual specialists who carry out traditional ceremonies are called ajq'ijab' in the K'iche' language, which means "they of the sun, or day." I will use the highland Maya term ajq'ijab' throughout this paper rather than daykeepers, shamans, or priests which are sometimes used in English. None accurately convey the meaning of the term and can be misleading. Maya ajq'ijab' believe that their sacred ancestors, who set the pattern for contemporary rituals, continue to live in their blood and can be awakened at appropriate times and under appropriate circumstances. It is this sacred ancestral vision that allows the ajq'ijab' to "see" beyond the limits of time and distance as the first people once did (Figure 1). Evon Vogt wrote that the Tzotzil-Maya of Zinacantán 


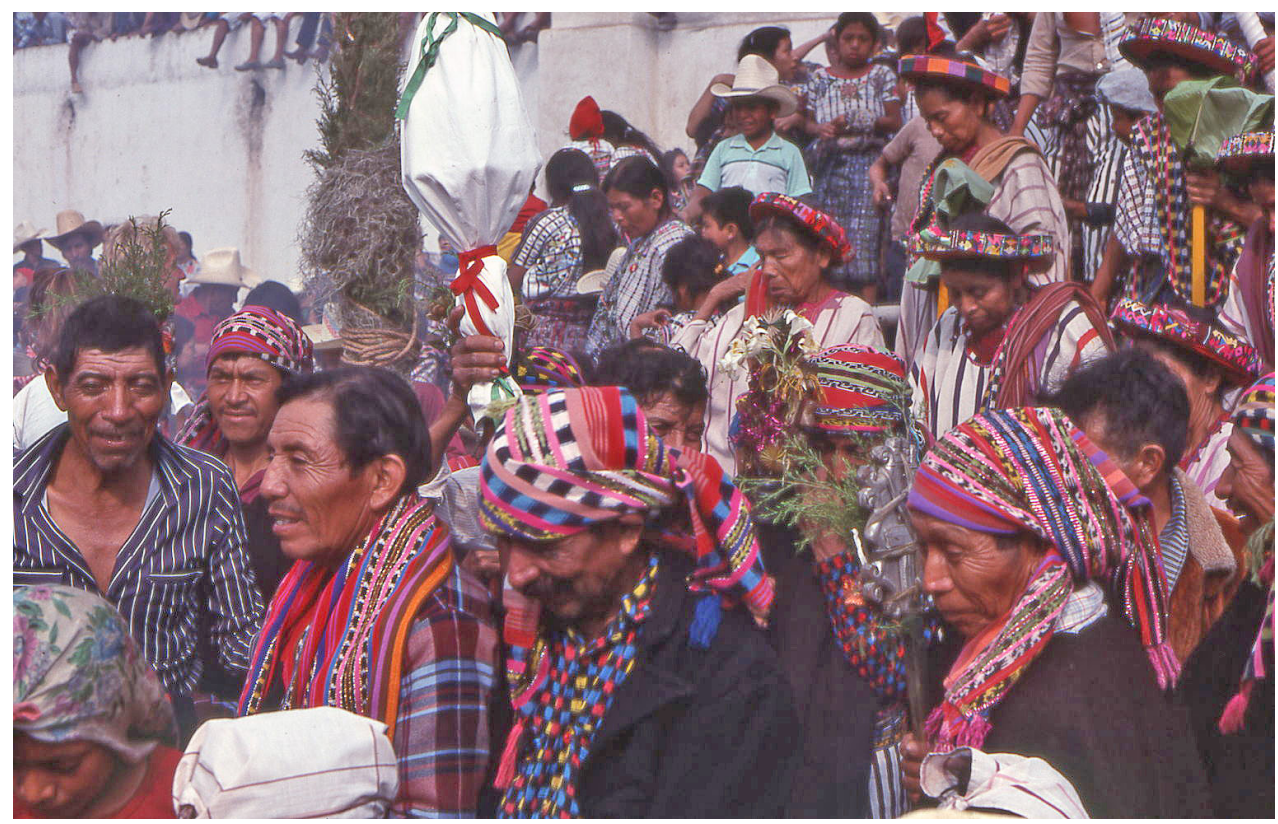

Figure 1. Ceremonial procession, Santiago Atitlan (A. Christenson)

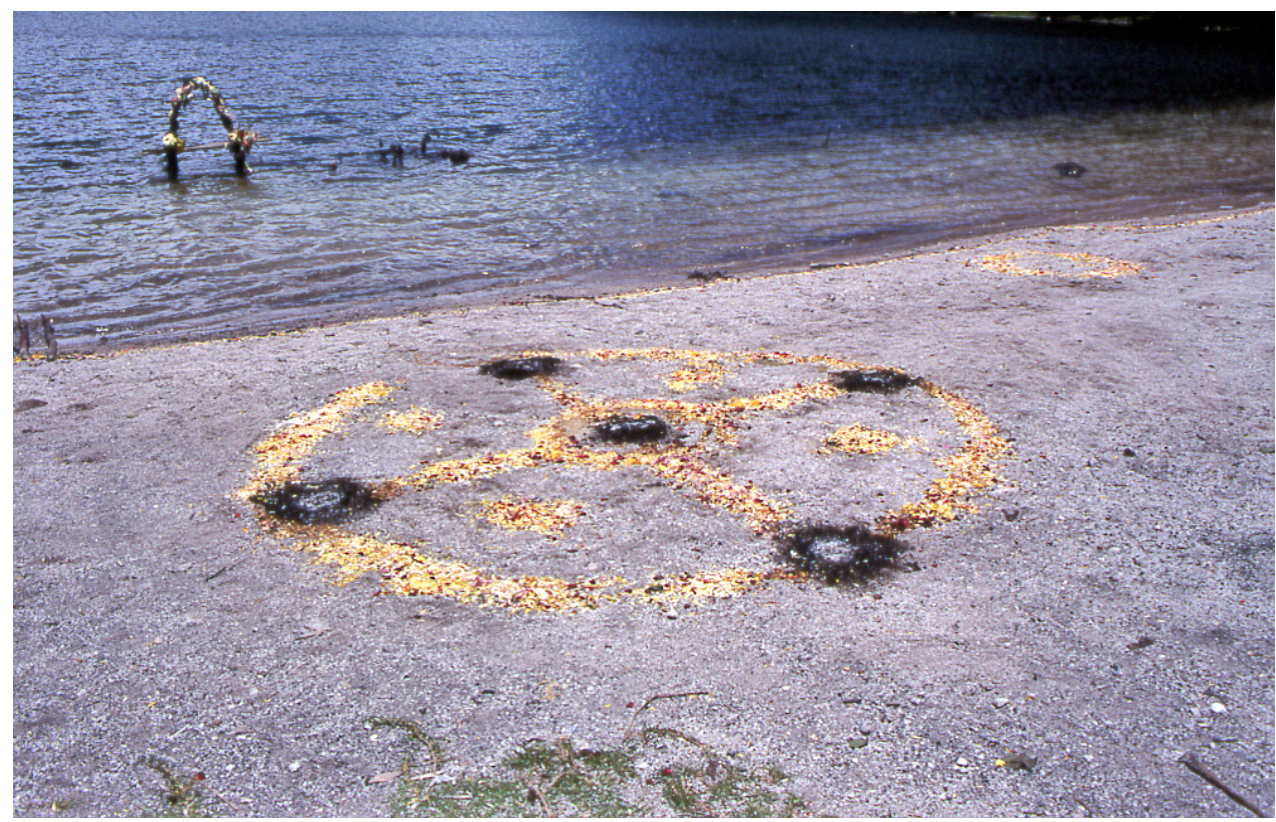

Figure 2. Cosmogram, Lake Chuwi'kab’al (A. Christenson) 


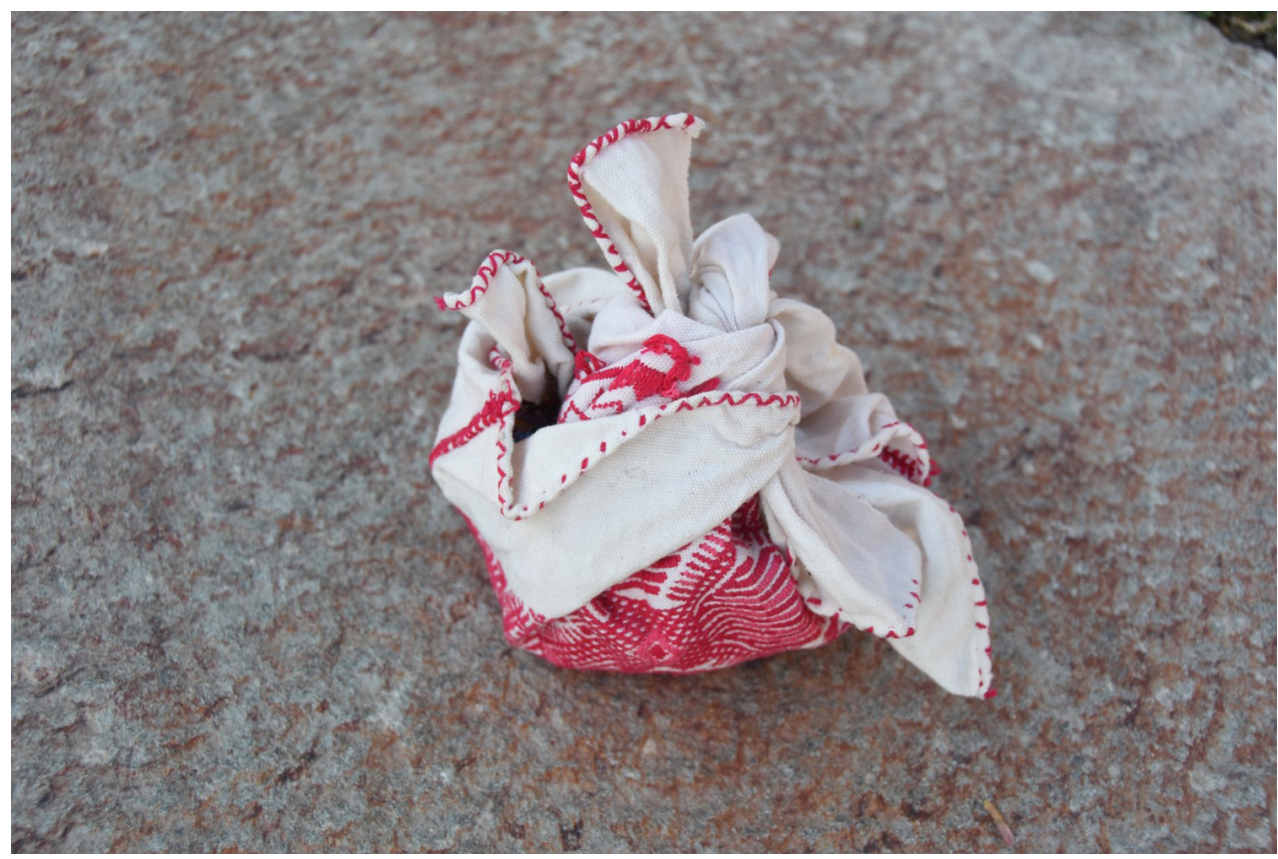

Figure 3. Ajq'ij bundle (wrapped) (A. Christenson)

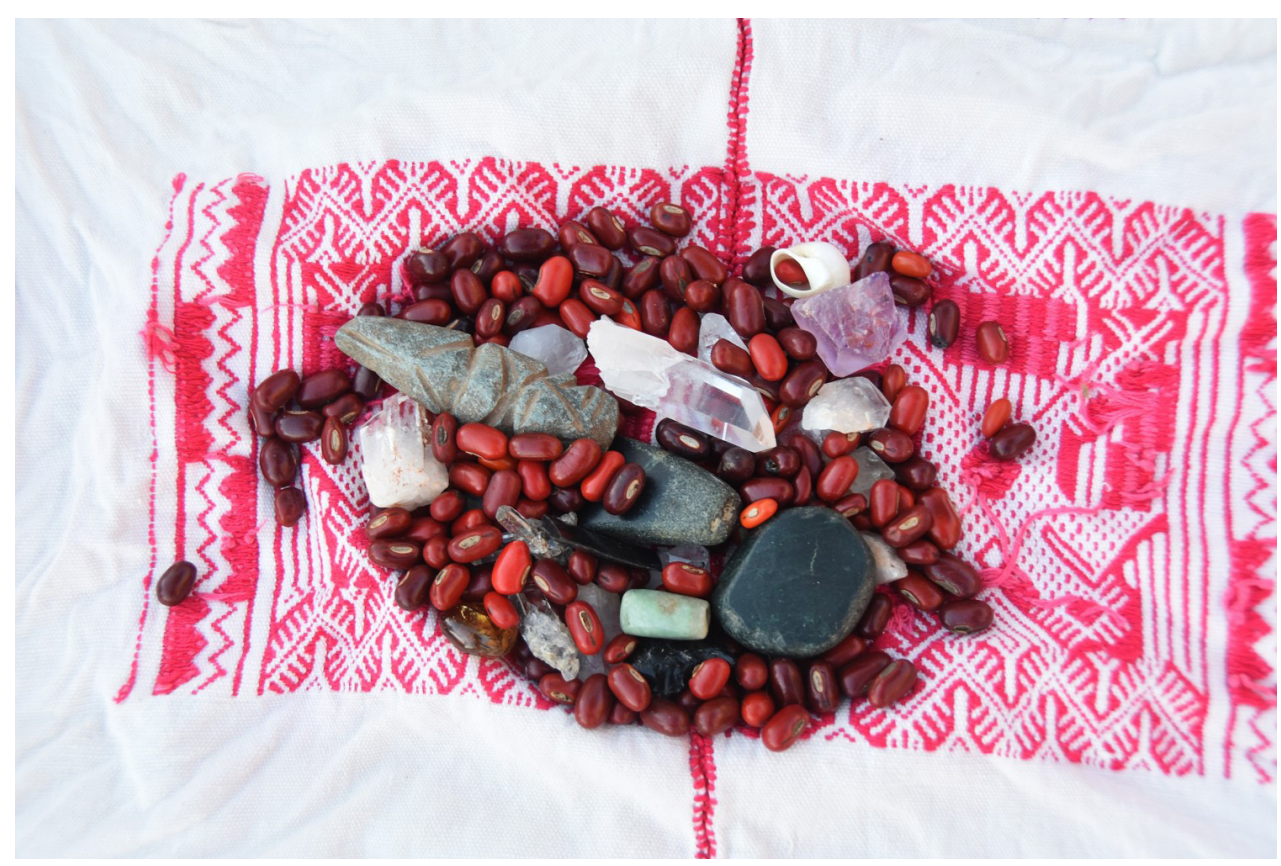

Figure 4. Ajq’ij bundle (unwrapped) (A. Christenson) 
believe that anciently their people could see inside sacred mountains where the ancestors live. The very word Tzotzil is in part derived from the root -il ("to see"), implying not only vision, but insight or sacred knowledge. Thus the Tzotzil term h'ilol means "seer," in the sense of one who can "see" things on a supernatural level (Vogt 1993:205).

Among the Maya, there is no institution or bureaucracy religion to sanction the qualification of a person to become an ajqij. Every Maya man and woman potentially has this ability because it is inherent in their blood. Ajq'ijab' are chosen by the ancestors to serve as mediators between this world and that of the spirit not because they are qualitatively different from anyone else, but because they are called by the spirit world to do so as a service to the community. Once called, generally through dreams or the discovery of a sign interpreted as an invi-

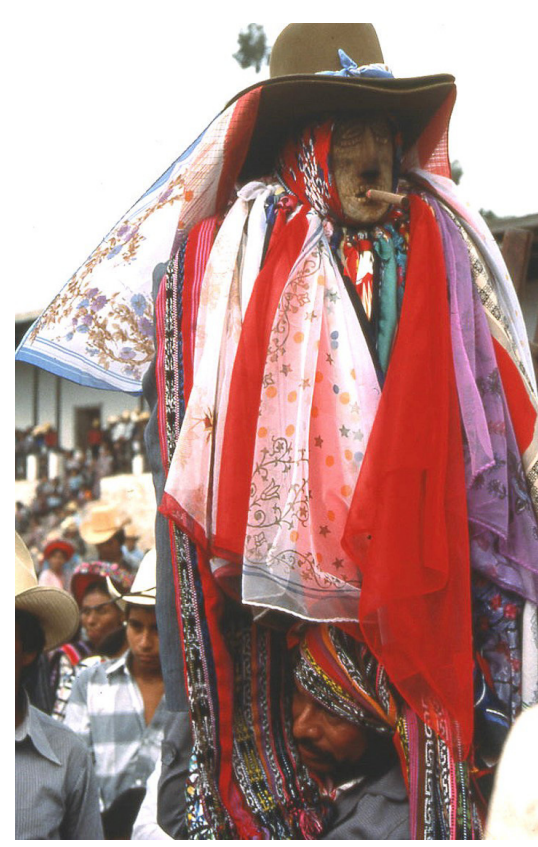

Figure 5. Rilaj Mam, Santiago Atitlan (A. Christenson) tation from the ancestors to serve, the prospective ajqij often enters a period of apprenticeship. The approach that experienced ajq'ijab' take in training their apprentices is to teach how to interpret signs and spirit communication, often described as lightning in the blood, that they had always received since young childhood but had not the experience to understand properly. Ruth Bunzel wrote in the 1950s that ajq'ijab' have no special relationship with divinity, and their prayers, though perhaps more eloquent, are no more powerful than those that are voiced by any Maya person (Bunzel 1952:299). This is because every Maya has the blood of his or her ancestors and traditionalist Maya believe that blood carries the soul and knowledge of those ancestors.

A prospective ajq'ij generally undergoes a period of training under an experienced person who already holds the title. Ideally, this training continues for two hundred and sixty days, the same number of days as the traditional Maya calendar. It is also approximately the length that a human child develops in the womb of its mother. Thus, when apprentices complete their training, they are considered reborn. During this time, the prospective ajq'ijab' often live with their teacher and observe everything that she or he does. The period of instruction begins on the evening of a new moon and ends on an evening with a full moon. After the period of apprenticeship is completed, the apprentice receives the title of ajq $i j$ and is presented by his teacher with her or his own bundle. This is a particularly sacred location called Chuwi'kabial that is often used for receiving the bundle-a high volcanic lake with flowery altars laid out to represent the world and the four cardinal directions. 


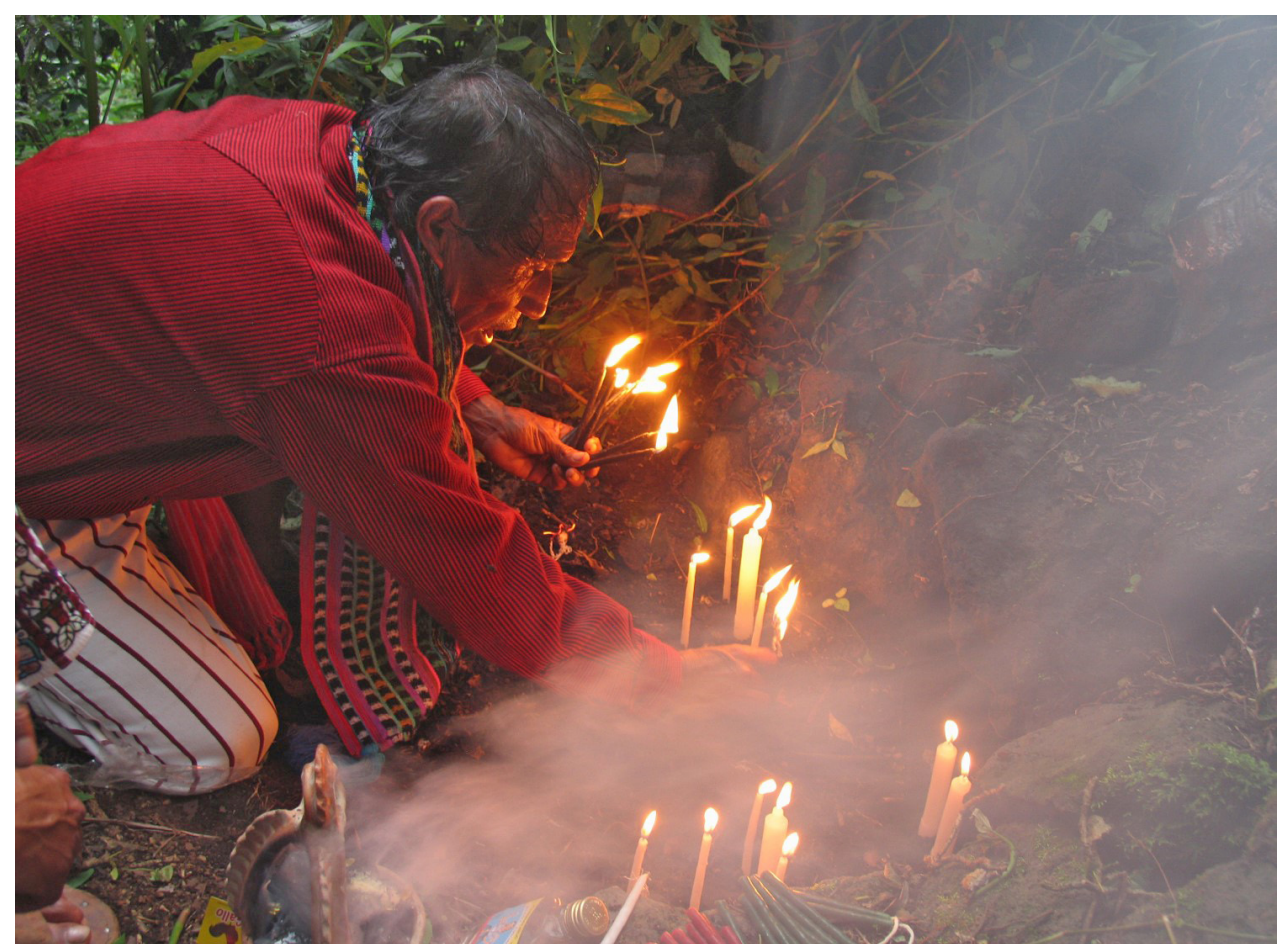

Figure 6. Ceremony at the Rilaj Mam Shrine above Santiago Atitlan (A. Christenson)

The ajq'ij's bundle is generally made of woven cloth containing approximately two hundred seeds, preferably the red seeds of the $t z^{\prime} i t e$ or coral tree, although some ajq'ijab' may use maize kernels. mixed in with the seeds are pieces of obsidian, jadeite, quartz, and fragments of ancient stone or terra cotta artifacts (see Figure 6). Divination using $t z^{\prime}$ ite seeds is closely related to the 260 day traditional Maya calendar and is used extensively throughout the highlands of Guatemala (Ximénez 1977:88; Schultze Jena 1954; Douglas 1969:103, 154-55; B. Tedlock 1982; Watanabe 1992:188). Ceremonies conducted with the $t z^{\prime}$ ite seeds are believed to reveal the knowledge of the ancestors and deities to help those with illnesses or other significant difficulties in people's lives.

The Popol Vuh notes that prior to the first dawn of the sun and the creation of the first generation of true human beings, several unsuccessful attempts to create people were carried out by a pair of aged grandparent gods. Prior to the last of these unsuccessful attempts, the creator gods performed a divination ceremony in which grains of maize and $t z^{\prime}$ ite seeds were cast, no doubt a similar ceremony to those conducted by ajq'ijab' today:

Thus began the divination ceremony, the casting of grains of maize and of $t z^{\prime} i t e$, the revelation of days and of shaping. Then spoke the one Grandmother and the one Grandfather to them. 
For this was the Grandfather, the Master of the Tz'ite, Xpiyacoc by name. And this was the Grandmother, the Mistress of Days and the Mistress of Shaping who is at the foot, who is called Xmucane.

Thus they began to speak, to carry out their divination ceremony:

"May it be discovered. May it be found. Say it! Our ears hear you. Speak! Tell it! May the tree be found that is to be carved and chiseled out by the Framer and the Shaper. If this is to be the provider and the sustainer, then may it now be sown that the dawn may come. You, grains of maize, and you, $t z$ 'ite; you, days, and you, the shaping- you are called, you are summoned." Thus it was said to the grains of maize and the $t z$ 'ite, to the days and the shaping. (Christenson 2007:82).

In modern practice, ajq'ijab' also speak directly to the tz'ite seeds as they carry out their divinatory ceremonies, urging them to give an accurate and true answer to their petition, just as in this passage from the Popol Vuh.

As a result of this divination ceremony, the men of the wood were created, carved from the wood of the same $t z$ ite tree from which the divinatory seeds were taken. Although the wood people failed to remember their creators and thus lost their position as the principal mediators between this world and the next, the incident suggests that certain carved wooden effigies belong to a previous creation and are thus more ancient than the world in which we live. Among the Tz'utujil-Maya, the wood of the $t z^{\prime}$ ite tree is still considered to have extraordinary power, including the ability to speak and predict the future (Orellana 1984, 98). In Santiago Atitlán, traditionalists venerate an effigy carved of $t z$ ite wood that they call Rilaj Mam (Ancient Grandfather) or alternatively Maximon (Ancient One Who is Bound) (Figure 10). The trunk of this effigy is approximately $76 \mathrm{~cm}$ in height and $15-20 \mathrm{~cm}$ thick, with separate pieces of wood attached to form the head and legs. A carved mask with a roughly hewn face is tied about the head. This effigy is said to be more ancient than Christ, having been created "in the beginning of time, or of the world" (Mendelson 1959, 58, 60). Although powerful, Rilaj Mam is considered dangerous and unpredictable and does not conform to the rules of society. The Mam figure may be a remembrance of the chaotic world prior to the creation of humankind when the gods were not remembered or worshiped properly by the $t z^{\prime}$ ite wood people described in the Popol Vuh.

Rilaj Mam, being made of $t z^{\prime}$ ite, is also the patron of all ajq'ijab'. The place where the Mam figure was first carved in the mountains east of the present day town of Santiago Atitlán is frequently visited for particularly powerful divination ceremonies. At this shrine one can still see the stump of the tree from which he was carved. Below the stump is a small cave-like entrance surrounded by remnants of pine needles, white candles, and incense ashes from previous ceremonies. It is said that the cave-like hole is one of the principal entrances into the underworld where the Mam reigns and where ajq'ijab' can consult the ancestors and deities.

Not all ajq'ijab' go through a process of apprenticeship. A well-respected $a j q^{\prime} i j$, named Diego in Santiago Atitlán told me that although he had watched 


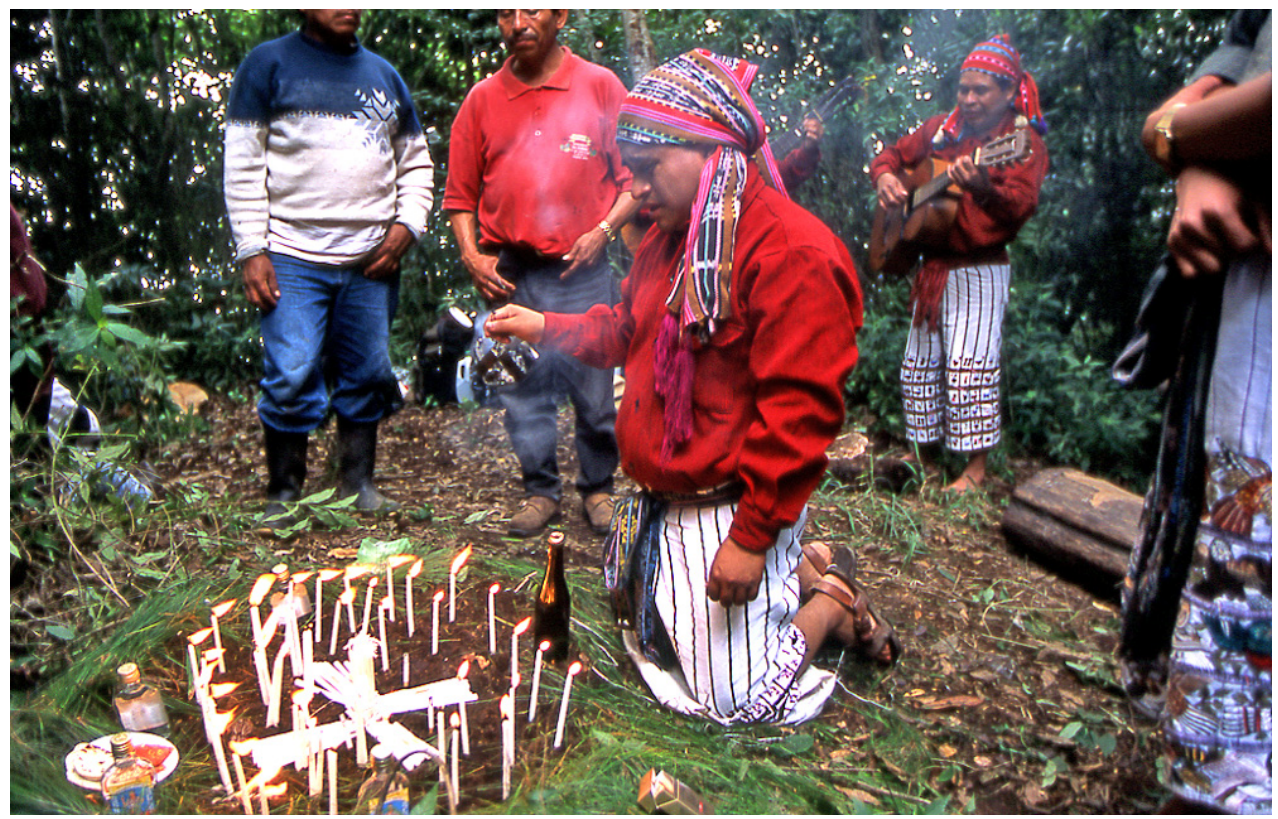

Figure 7. Petition Ceremony, Santiago Atitlan (A. Christenson)

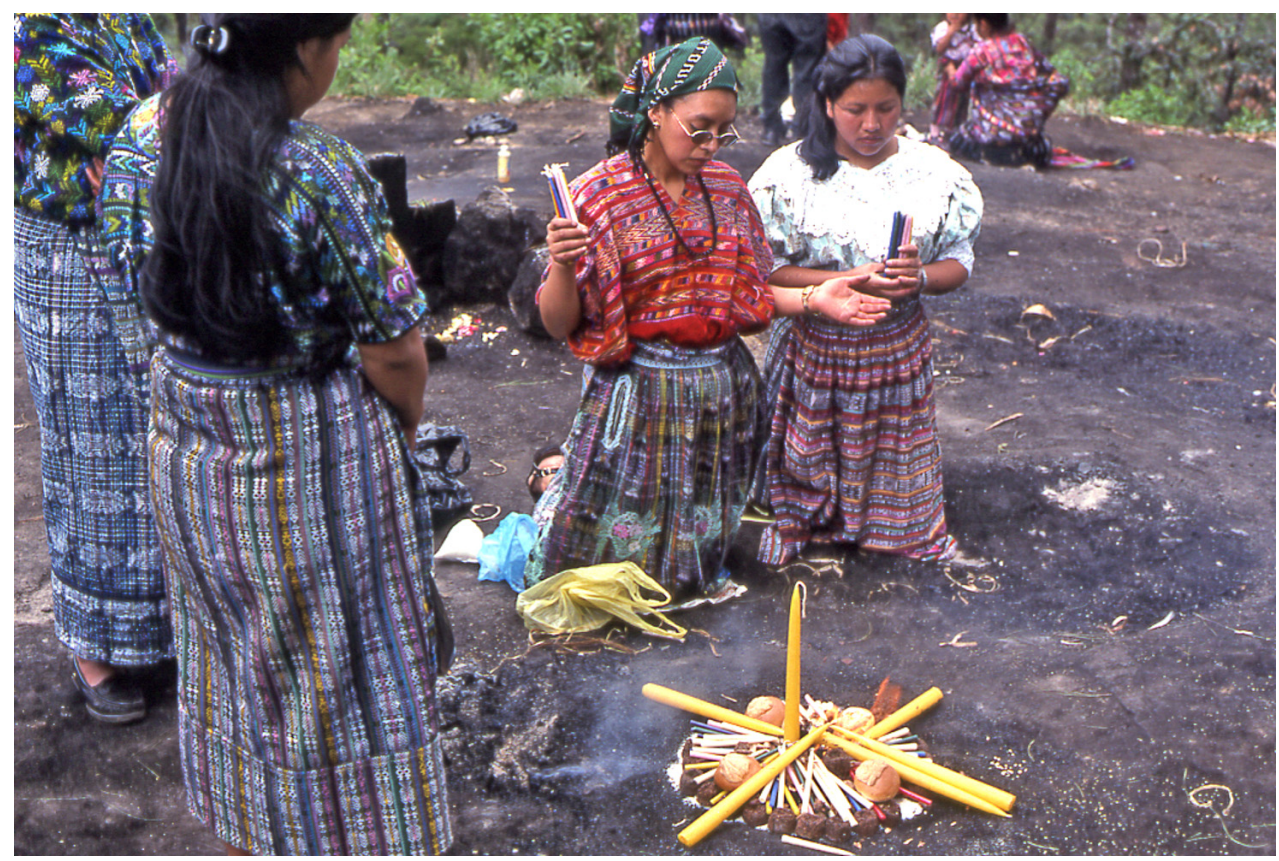

Figure 8. Ajq'ij performing a healing ceremony, Chichicastenango (A. Christenson) 


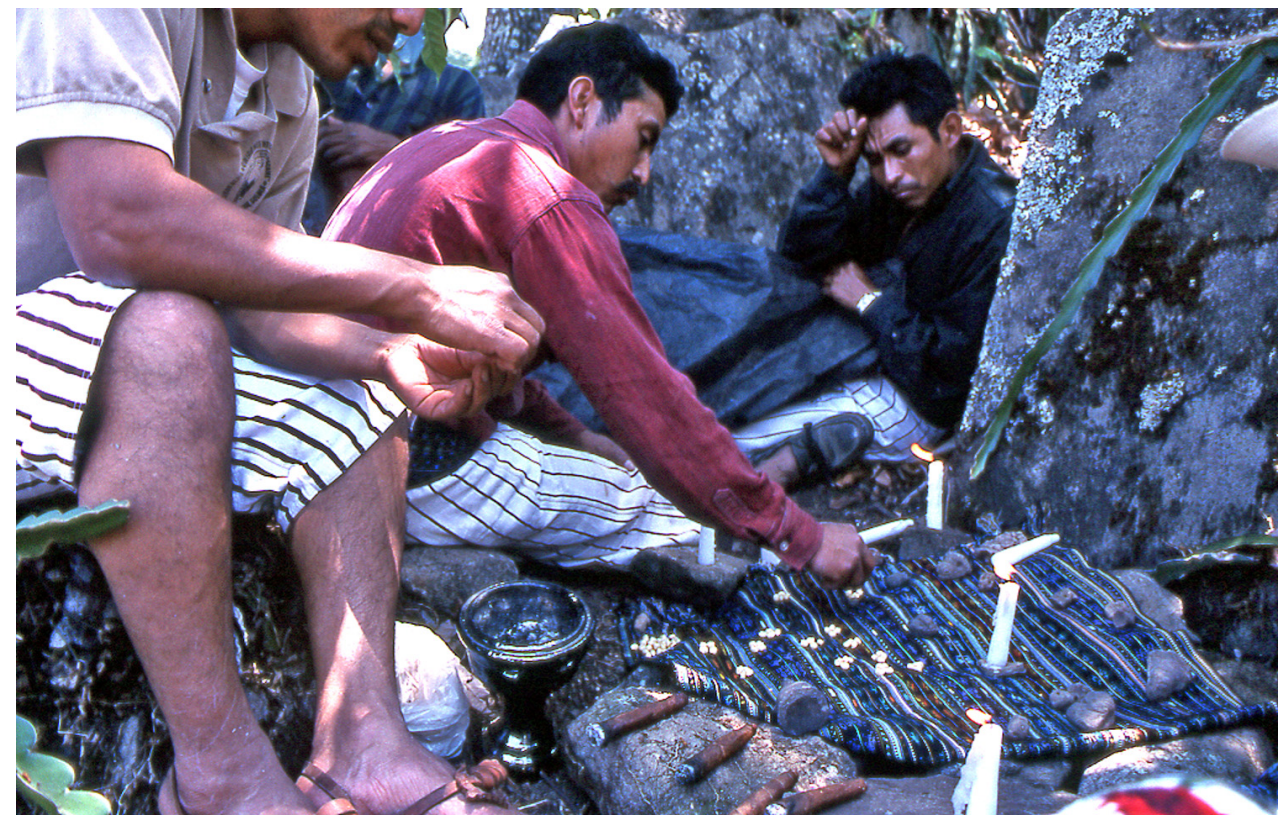

Figure 9. Ajq'ij divination ceremony, Chutinamit (A. Christenson)

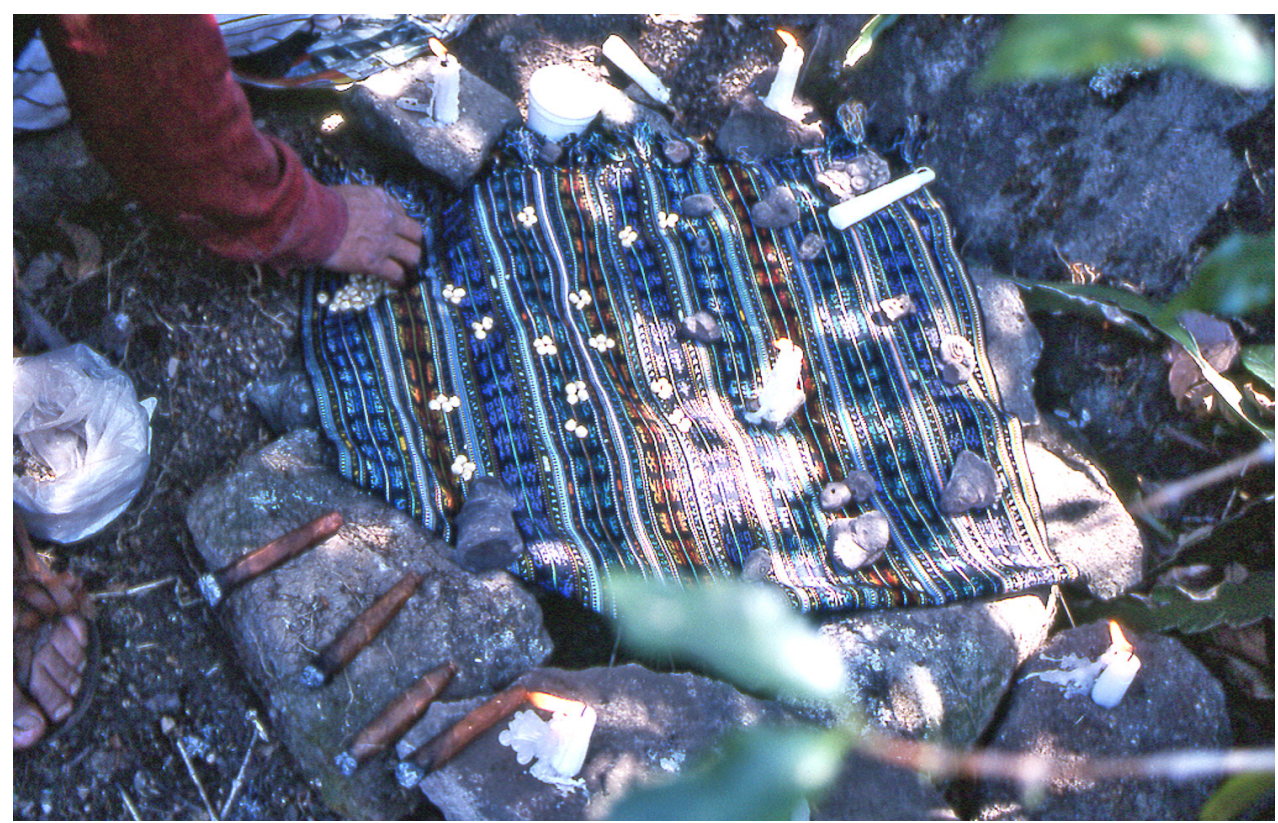

Figure 10. Ajq'ij’s mesa, Chutinamit (A. Christenson) 
a number of elderly ajq'ijab' carry out prayers and ceremonies in his youth, he did not learn how to do his work from them:

When I was born, I already knew how to do these things. I had no teacher. I speak with the ancestors and ancient kings and they speak with me. They help me to know how to heal and solve problems for people. I ask the ancestors these things in places that are holy where I can be touched by them.

Michael Mendelson was told by an ajq'ij that sacred knowledge cannot be passed from one person to another. It must come from otherworldly sources:

He said that a young man who wished to be an $a j q^{\prime} i j$ tried to learn the prayers, bit by bit, from another $a j q$ ' $i j$ but that there were no direct courses or lessons given by an old man to a pupil and that there could not be since these things came from God. For this reason each $a j q^{\prime} i j$ had a different way of praying (Mendelson 1957:280-281).

Apprenticeships, and learning by example, are undoubtedly important methods of passing along knowledge from one generation to another, however, the perception among Maya ajq'ijab' is that this is not the principal means by which sacred knowledge is gained. This must come directly from within oneself, directly from their own blood, or it is powerless. Non-Maya do not necessarily have this kind of ability, because their blood did not come from the same visionary ancestral source. I apprenticed with an ajq'ij in Momostenango in the late 1970s. At the time, my slowness in learning divinatory and calendric skills was interpreted as the lack of Maya blood in my veins. I was not able to see with ancestral vision in the same way as the K'iche' apprentices because I did not have Maya blood. My ancestors did not have knowledge of the Maya calendar and ceremonies and therefore they could not help me. The ajq'ij that I apprenticed with often told me that one doesn't memorize calendrics, prayers, or other complicated ceremonies. They teach themselves to remember what they already know in their blood.

Ruth Bunzel wrote that the K'iche' of Chichicastenango claimed that their formal speech and ceremonies came from ancient ancestral precedent: "And now this rite and custom belongs to the first people, our mothers and fathers.... This belongs to them; we are the embodiment of their rites and ceremonies" (Bunzel 1952:232, 238). To alter the words or actions of the ancestors would be to change the very fabric of their existence in potentially destructive ways. As mediators between this world and that of the sacred, it is the Maya's obligation to continue the work of their divine ancestors in as an authentic manner as possible: When asking Tz'utujils when certain rituals began, a common response is that they are as old as the world and were first performed by their ancestors who had divine power (Christenson 2001:22-23, 68; Mendelson 1965:91).

At the beginning of ceremonial prayers, ajq'ijab' in Santiago Atitlán call upon a long list of sacred beings and objects whose power they wish to invoke 
on behalf of their clients. Prominent in this list are the "Holy Table" and the "Holy Chair" used in divination ceremonies. These objects are considered living beings with their own souls. Possession of a divinatory table implies acceptance of the role of shaman and responsibility to act as a mediator with spirit beings (Mendelson 1957:281; B. Tedlock 1982:74). This table may be an actual table or altar within the home, or it may be any flat surface utilized for ritual purposes. In 2006 I accompanied an $a j q^{\prime} i j$ in Santiago Atitlán to conduct a ceremony on a group of ruins called Chutinamit. The ajq'ij chose this location because he believed that there it was "closer to the kings of old and is therefore sacred." Prior to the ceremony he selected twelve flat stones and arranged them into a rough square which he called his "Holy Table" before laying out a clean cloth and arranging his ritual objects for the ceremony. He said that the makeshift altar had the same power as the tables and/or altars on which sacred objects are kept in his home. He placed four lit cigars on the north side of this temporary table so that the ancestors who were called upon to be present at the ceremony could smoke and be content (Figure 3).

The four corners of a ceremonial table's surface represent the four corners of the world and the placement of objects upon it suggests the arrangement of specific locations on the earth such as mountains or shrines. The table thus represents the sacred geography of the world in a form that becomes intimate, close, and potentially controllable. Evon Vogt quoted a highland Maya man from Zinacantán who expressed a similar understanding of the world, saying that the universe is "like a house, like a table" representing that which is systematic and well-ordered (Vogt 1993:11). Charles Wisdom also recorded that the Chortí-Maya of Guatemala considered both the squared maize field and the shamanic altar as the world in miniature (Wisdom 1940:430). By laying out the maize field, or setting up a ritual table, the Maya transform a physical object into sacred space. With regard to the maize field, this charges the ground with the power of creation to bear new life. In a similar way, the ceremonial table provides a stage on which sacred geography may be intimately studied, and even altered. The possession of a ceremonial table allows the ajq'ij the ability to manipulate the world itself with divine power and sight inherited from their first ancestors.

When the ajq'ij sits at his table, he places himself in a transcendent role that bridges the three layers of the cosmos. His legs extend beneath the surface of the table, representing the surface of the earth. His arms manipulate its sacred geography, while his upper body rises into the upperworld. In so doing, the ajq'ij is able to "see" all places where the spirit beings live and converse with them. The ajq'ij who sits at this table thus acts as the representative of the first ancestral priest who set the precedent for such ceremonies. In a similar way, the ajq'ijab' of the Tz'utujil-Maya are believed to carry within their blood the power by which they are able to pray "according to the ancient words of god" (Mendelson 1957:281). 


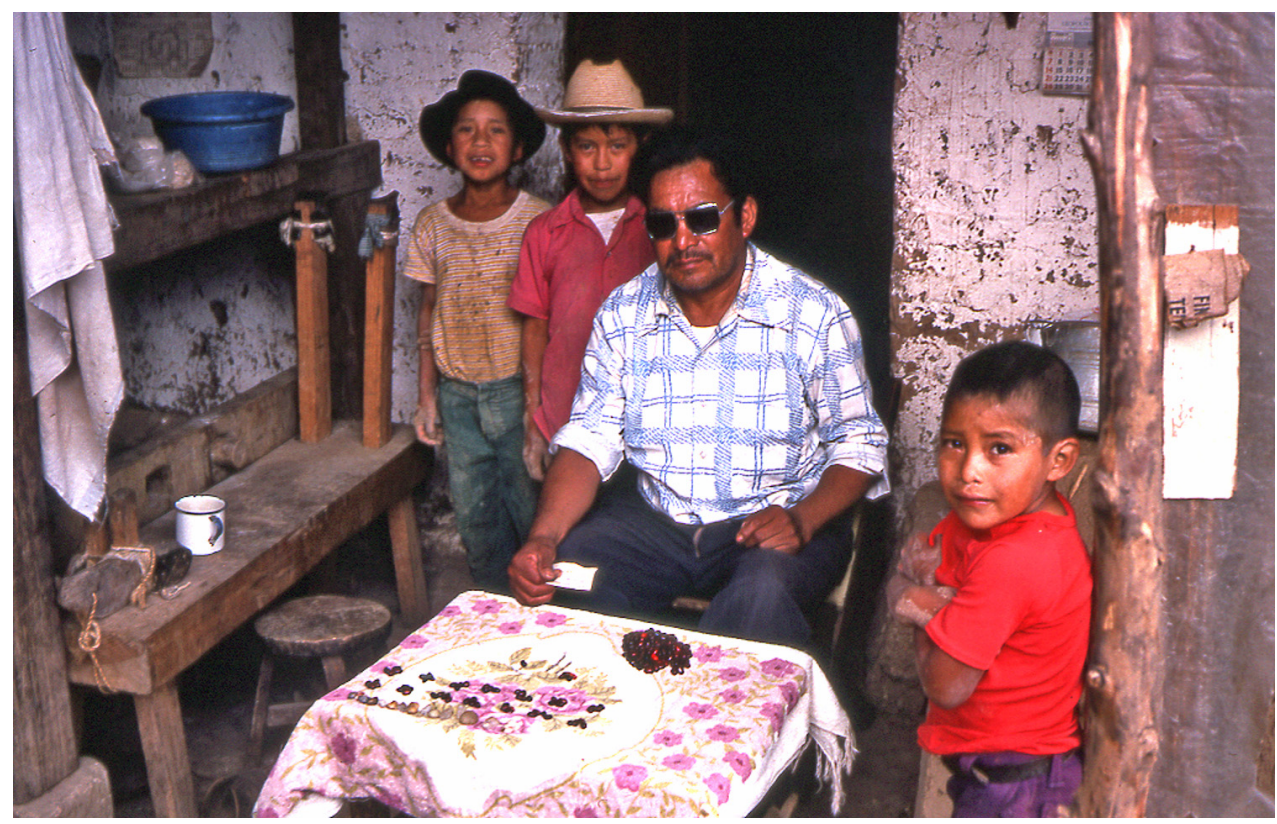

Figure 11. Ajq'ij at his ceremonial table, Momostenango (A. Christenson)

In the K'iche' community of Momostenango, a prominent ajq'ij told me that when he sits at his table, he becomes a living representation of the organization of the world:

When I am seated at the table, I am aj nawal mesa. My body is in the form of a cross just like the four sides of the world. This is why I face to the east and behind me is the west. My left arm extends out toward the north, and my right arm points to the south. My heart is the center of myself just as the arms of the cross come together to form its heart. My head extends upward above the horizon so that I can see far away. Because I am seated this way I can speak to the World.

The ritual table is called either the Santa Mesa (Spanish for "Holy Table") or, as described in the previous quote, with the K'iche'-Maya term Nawal Mesa. The word nawal has no English equivalent that embraces all its various meanings. In K'iche' theology everything, both living and inanimate, has a spirit essence or nawal. This spirit essence is believed to give humans, animals, and even inanimate objects, like trees or mountains, the power to communicate on a supernatural plane. Although originally borrowed from the central Mexican Nahua group of languages, modern-day highland Maya associate this word with the verbal root $n a$, meaning "to feel," "to know," or "to remember." In the Popol Vuh, the creator deities themselves brought the first mountains out of the primordial sea at the dawn of creation by means of their nawal, their spirit essence, rather than by physical action (Folio 
33 recto, translation by author). It was by this same power that the first ancestors of the Maya were created by deity:

Merely by miraculous power and nawal (spirit essence) was their framing and shaping brought about by the Framer and the Shaper, by She Who Has Borne Children and $\mathrm{He}$ Who Has Begotten Sons, by Sovereign and Quetzal Serpent. (Christenson 2007: 197)

Nawal may refer to the power of any object, person, or god that has supernatural qualities, but it may also refer specifically to deified ancestors. Thus the authors of the Title of Totonicapán described their ancestors as "Nawal People" who performed powerful, miraculous works at the beginning of time (Carmack and Mondloch 1983:folio 84, lines 1-2).

In the highland Maya understanding of the term, nawal is most com-

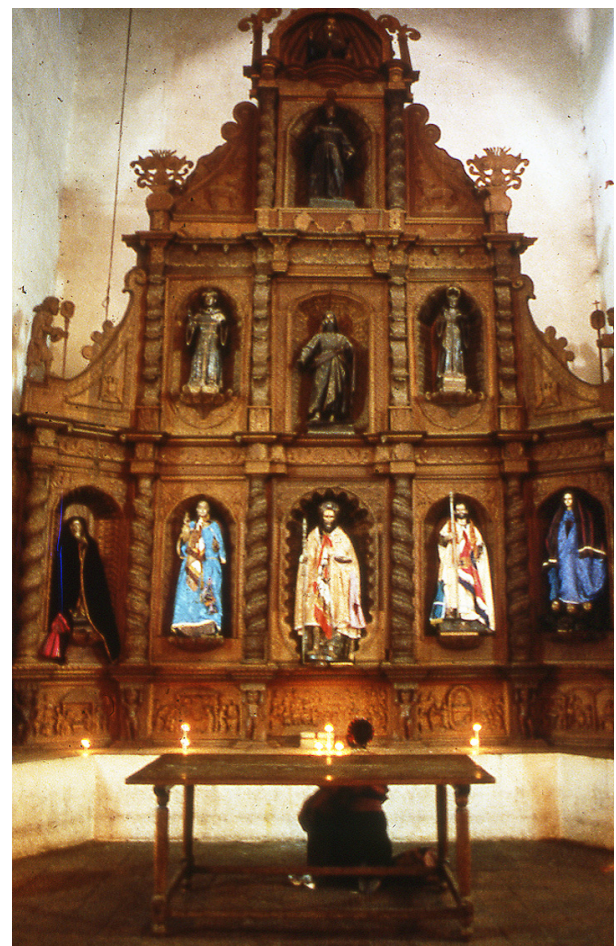

Figure 12, Central Altarpiece, Church, Santiago Atitlan (A. Christenson) monly used to describe a great ancestor or ajq'ij of the past who had the power to work miracles (Mendelson 1957:42). When a living ajq'ij repeats the actions of a nawal ancestor through ceremonies or prayers, he/she becomes a substitute or vessel for sacred power.

The $a j q^{\prime} i j$ functions as a living representative of deity or his own sacred ancestors when he sits at the Nawal Mesa. A common misconception is that the Maya of the Guatemalan highlands worship their ancestors as separable entities. This is not true. The Maya recognize the divinity that is inherent within themselves. They are the embodiment of the ancestors, and therefore they are constantly present within them, particularly within their blood. In a very real sense every Maya individual is an expression of ancestral power. A young traditionalist Maya ajq'ij in Santiago Atitlán once told me, "As the old people say, when the Spaniards came they broke off many of our branches. They even burned the trunk. But we will never die because the roots have power. We draw strength from the ancestors who live in our blood. If we as a people ignore our roots, only then will we all die." One of the highest titles held by the priest-shamans of Momostenango is chuch-qajaw ("mother-father") as he represents a living manifestation of his ancestors. As such, he is able to act in their name because he possesses their blood. It is essential, therefore, that he approach the duties of his office with great seriousness and in a state of ritual purity. 


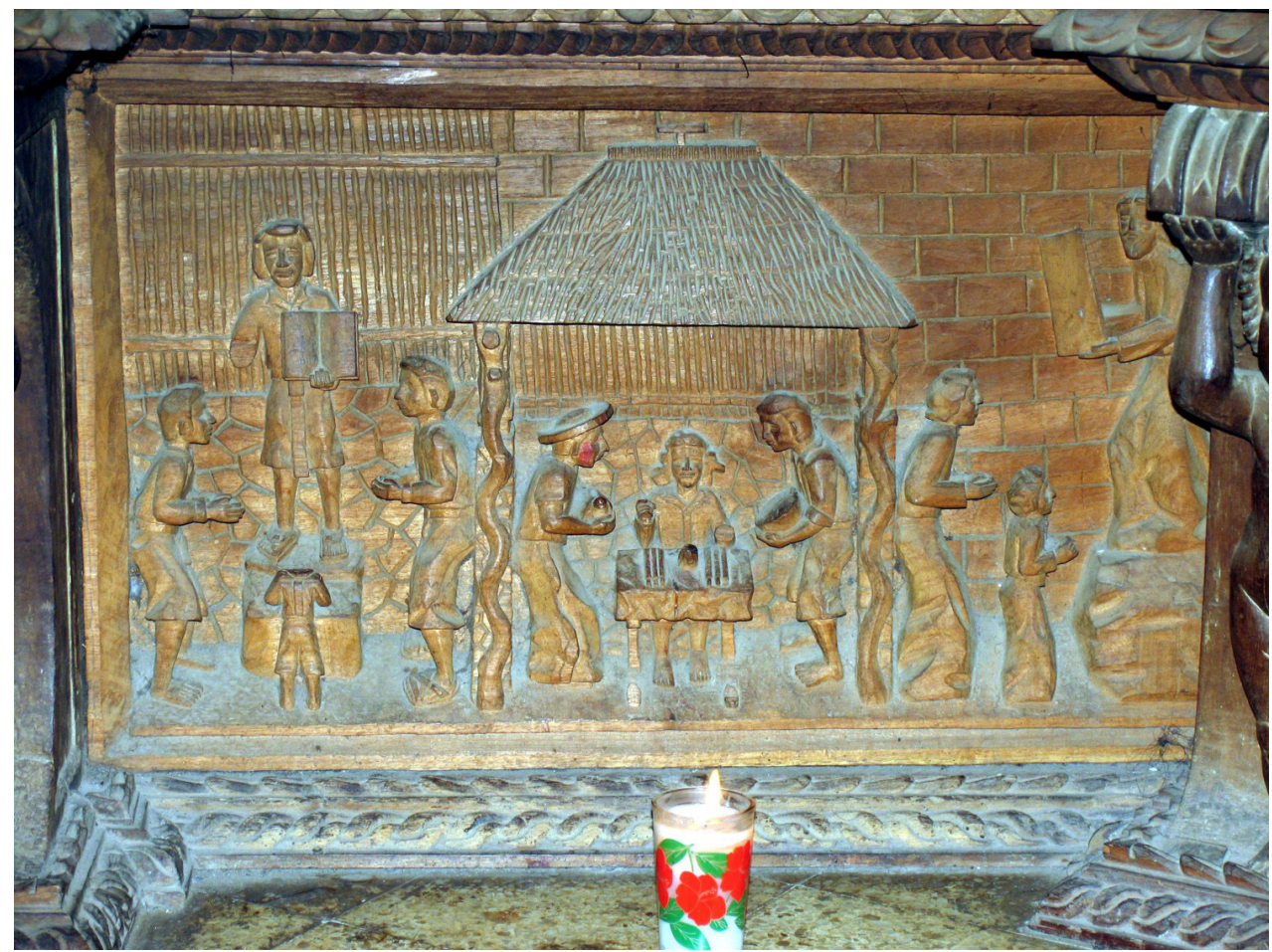

Figure 11. Ajq'ij at his ceremonial table, Momostenango (A. Christenson)

Non-Maya believe that memory is a function of the brain. The Maya see memory as coming from the blood. These are not just individual memories, but the thoughts and memories of their parents, grandparents, and all the ancestors back to the first creation. They believe that these memories may be called upon ceremonially.

There is a carved depiction of a ceremonial table on the central altarpiece of the church in Santiago Atitlán. Originally constructed at an unknown date during the early Spanish Colonial period, the altarpiece fell into severe disrepair and collapsed during an earthquake in 1960. The broken pieces of the fallen altarpiece were left in storage until 1976 when the parish priest, Father Francisco Rother, commissioned a local Maya sculptor named Diego Chávez Petzey to initiate repairs and carve replacement panels for those portions of the altarpiece which were too damaged to be used. Rather than simply restoring the altarpiece to its original design, Diego Chávez subtly modified it to give the impression of a sacred mountain with niches representing caves from which the patron saints of the town emerged. At the base of the altarpiece, Diego carved a series of five panels of his own design representing traditional Maya ceremonies meaningful to his community.

According to Diego Chávez, the first panel represents the revelation of divine will in the life of a Maya child as mediated through an ajq'ij: 
The scene represents a child's naming and blessing ceremony. The $a^{\prime} q^{\prime} i j$ is in the center of the panel seated behind his table. The ajq' $i j$ prays to "Heart of Sky, Heart of Earth" to determine what blessing the child will receive, whether he will grow well and what he will come to be. The man on the right is the child's father, holding a book containing the count of days. Many years ago, ajq'ijab' were much more powerful than now and knew how to read the days, the clouds, and the calls of animals. I've been told by old people that some of them kept books filled with ancient knowledge. So I included one in the panel to show that our ancestors also had writings containing revelations from the spirit world

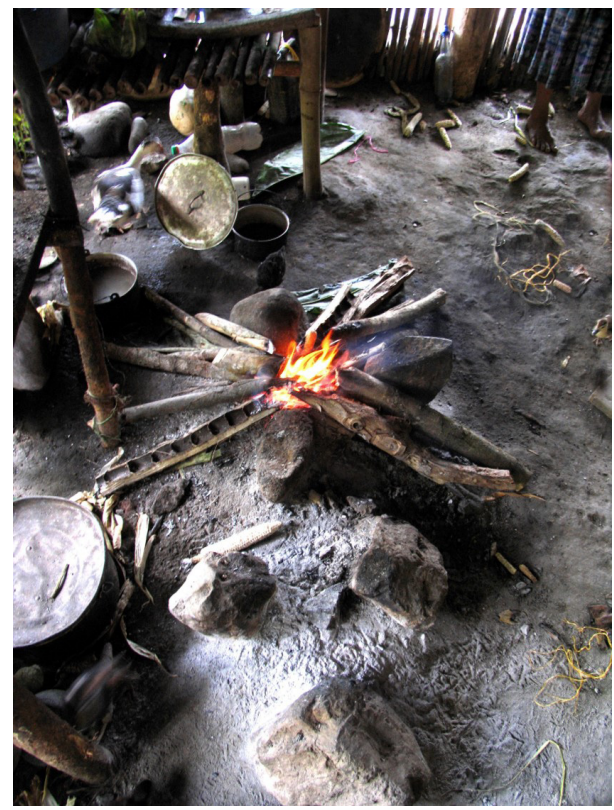

Figure 12, Central Altarpiece, Church, Santiago Atitlan (A. Christenson) that were equally as powerful as the words in the Bible. All these books are now gone though and ajq'ijab' today aren't as powerful as our ancestors once were. The woman on the left is the child's mother. It is a boy child, so he is on the ajq'ij's right-hand side. If it had been female, the child would have been on the other side. On the table are candles, incense, a piece of an old Maya clay head like farmers find in their fields, and a quartz crystal. When an ajq'ij looks into the crystal he sees little flashes of light that speak to him. Atop the ajq' 'ij's house in the panel is a cross. This is not a Christian cross, but represents the four cardinal directions with the house being the center place. The twisted posts in front of the house are like the serpents that guard sacred mountain caves where the saints and ancestors live. The stone blocks of the house represent the mountain itself. The maize canes and thatch above these stones are the maize fields, trees and vegetation that grow on the mountainside.

The objects on the ajq'ij's table as depicted on the altarpiece panel are still used in modern ceremonies. The small carved head is a fragment from a Precolumbian figurine. Small stone and terra cotta sculptures are relatively common in the area in and around Santiago Atitlán. Most Atiteco families, including Diego Chávez, keep a collection of them on their personal altars as relics of the ancestors. Each is considered a powerful sign of divine communication. Ajq'ijab' use them along with quartz crystals, jade, or obsidian flakes as ilbal ("instruments of seeing") whereby mountain or ancestral spirits may be consulted on behalf of their clients. 
A characteristic of Maya theology is the tendency to see seemingly ordinary and familiar things as shadows of the sacred. Laying out the boundary stones for a maize field is treated by traditionalists as no less than the delineation of the limits of the world, preparing it to give birth to new life as if it were the dawn of creation. The traditional three stone Maya hearth replicates the three stones of creation placed by the gods to serve as a foundation for the sky (Figure 12). Caves, or even small clefts in a mountain, are portals to the spirit homes of the ancestors and gods. These are not mere symbolic representations of the sacred, they are divine symmetries different in scale but not in their essential nature. Divination tables are therefore not merely symbols for the world. When used under appropriate circumstances they are "seen" as the world itself on a small scale. Ajq'ijab' who carry out ceremonies on the table's surface thus become vessels for sacred communication, replicating with the same power the actions of their ancestral parents who were created with visionary sight, transcending the limits of their immediate surroundings. It is this ancestral vision that the Maya believe gives them their identity and place in the world as mediators for the sacred.

\section{References}

Bunzel, Ruth

1952 Chichicastenango: A Guatemalan Village. University of Washington Press, Seattle.

Carmack, Robert M., and James L. Mondloch

1983 El Título de Totonicapán. Universidad Nacional Autónoma de México, Mexico City.

Christenson, Allen J.

2001 Art and Society in a Highland Maya Community: The Altarpiece of Santiago Atitlán. Austin, University of Texas Press.

2007 Popol Vuh. Norman, The University of Oklahoma Press.

2022 (in press) The Title of Totonicapán. University Press of Colorado, Boulder.

Coto, Fray Thomás de

1983 Thesaurus Verborum: Vocabulario de la Lengua Cakchiquel u [El] Guatemalteca, Nuevamente hecho y Recopilado con Summo Estudio, Travajo y Erudición., Universidad Autónoma de México, Mexico City.

Douglas, William

1969 Illness and Curing in Santiago Atitlán. Ph.D. dissertation, Stanford University, Stanford.

Goubaud Carrera, Antonio

1935 El "Guajxaquip Bats"-- ceremonia calendárica indígena. Anales de la Sociedad de Geografía e Historia de Guatemala, Vol. 12, pp. 39-59.

Helms, Mary W.

1993 Craft and the Kingly Ideal: Art, Trade, and Power. Austin, University of Texas Press. Hill, Robert M. II

1992 Colonial Cakchiquels: Highland Maya Adaptation to Spanish Rule 1600-1700. Holt, Rinehart and Winston, Fort Worth. 
Mendelson, E. Michael

1957 Religion and World-View in a Guatemalan Village. Microfilm Collection of Manuscripts on Middle American Cultural Anthropology, no. 52. University of Chicago Library, Chicago.

1965 Los escándalos de Maximon: Un estudio sobre la religión y la visión del mundo en Santiago Atitlán. Seminario de Integración Social Guatemalteca Publication 19, Tipografía Nacional, Guatemala City.

Oakes, Maud

1951 The Two Crosses of Todos Santos. Princeton University Press, Princeton.

Popol Vuh

1701 Manuscript version in Arte de las tres lenguas kaqchiquel, quiche y tz'utuhil. Transcribed by Francisco Ximénez. Ayer Collection at the Newberry Library, Chicago, Illinois.

2008 Popol Vuh. Relato maya del origen del mundo y de la vida. Versión, introducción y notas de Miguel Rivera Dorado. Editorial Trotta, Madrid.

Schultze Jena, Leonhard

1954 La vida y las creencias de los indígenas quiches de Guatemala. Biblioteca de cultura popular, vol. 49. Tr. Antonio Goubaud Carrera and Herbert D. Sapper. Ministerio de Educación Pública, Guatemala City.

Tedlock, Barbara

1982 Time and the Highland Maya. University of New Mexico Press, Albuquerque.

Vogt, Evon Z.

1993 Tortillas for the Gods: A Symbolic Analysis of Zinacanteco Rituals. University of Oklahoma Press, Norman.

Wisdom, Charles

1940 Chorti Indians of Guatemala. University of Chicago Press, Chicago.

Ximénez, Fray Francisco

1967 Escolios a las historias de origen de los indios. Sociedad de Geografía e Historia, Guatemala City.

1977 Historia de la Provincia de San Vicente de Chiapa y Guatemala de la orden de Predicadores. Vols. 1 and 2. Sociedad de Geografía e Historia, Guatemala City. 